\title{
Membaca Undang-Undang Nomor 44 Tahun 2008 Tentang Pornografi dari Perspektif Sosiologi Hukum
}

\author{
Murdan \\ Institut Agama Islam Qamarul Huda, Nusa Tenggara Barat
}

\begin{abstract}
Abstrak
Sebagai masyarakat yang terkenal dengan kekayaan suku, budaya, enis, golongan, bahasa, pulau, dan seterusnya, wajar jika Indonesia dikatakan sebagai salah satu negara di planet dunia yang paling multikultural. Disahkannya Undang-Undang Nomor 44 Tahun 2008 tentang Pornografi sebagai keberhasilan keras kalangan Islamisme menembus legislasi nasional Indoensia. Akibatnya, kumpulan masyarakat yang tidak sepaham dan tidak setuju dengan pengesahan Undang-Undang Nomor 44 Tahun 2008 tersebut melakukan berbagai upaya perlawanan untuk membatalkan Undang-Undang itu. Perlawanan yang mereka lakukan dari protes melalui gerakan demonstrasi, politik, ekonomi, hingga pada upaya menempuh jalur hukum. Alhasil, sampai hari ini Undang-Undang tersebut hanyalah sebagai penghias dokumentasi legislasi nasional Indonesia, dan hampir tidak lagi mendapatkan perhatian masyarakat dan penegakan hukum di Indonesia. Sehubungan dengan itu, tulisan ini akan membaca eksistensi Undang-Undang Nomor 44 Tahun 2008 Tentang Pornografi tersebut dalam perspektif sosiologi hukum, baik dalam diskusi ilmu hukum pada umumnya maupun dalam diskusi hukum Islam-Syariah.
\end{abstract}

Kata Kunci : Sosiologi Hukum, Maqasyid Syariah, Struktural Fungsional, dan Undang-Undang Nomor 44 Tahun 2008 tentang Pornografi.

\section{Abstract}

As a society known for its rich tribes, cultures, enis, groups, languages, islands, and so on, it is natural that Indonesia is said to be one of the countries on the world's most multicultural planet. The passing of Law No. 44 of 2008 on Pornography as a hard success among Islamism penetrated the national legislation of Indonesia. As a result, the group of people who disagreed and disagreed with the passage of Law No. 44 of 2008 made various resistance efforts to overturn the Law. The resistance they make from protests through demonstration movements, politics, economics, to efforts to take legal routes. As a result, to this day the Law is only as a documentation of Indonesia's national legislation, and almost no longer gets the attention of the public and law enforcement in Indonesia. In connection with that, this paper will read the existence of Law No. 44 of 2008 on Pornography in the perspective of legal sociology, both in the discussion of legal science in general and in discussions of IslamicSharia law.

Keywords: Sociology of Law, Sharia Maqashid, Functional Structural, Law No. 44 of 2008 on Pornography 


\section{A. Pendahuluan}

Undang-Undang Republik Indonesia No. 44 Tahun 2008 tentang Pornografi merupakan hasil aksi dan desakan keras masyarakat Muslim terhadap beberapa fakta mengenai aksi-aksi Pornografi yang dianggap melanggar dan bertentangan dengan norma Islam. Bagi kalangan Islamisme berpendangan bahwa, Islam melarang kegiatan pornografi dan pornoaksi, sehingga, jika idialitas agama melarang hal tersebut, maka seharusnya realitas kehidupan masyrakat harus tunduk dan patuh terhadap ajaran agama tersebut. Perbentuan antara realitas dan idialitas inilah yang memicu beberapa gerakan Islamisme melakukan aksi dan kecaman besar-besaran terhadap tindakan pornografi. Melihat desakan kalangan Islamisme tersebut, pemerintah kemudian memberikan sambutan hangat terhadap aspirasi kalangan Islamisme tersebut. Pemerintah mengakomudir aspirasi kalangan Islamise itu dengan tujuan untuk menghindari ketegangan sosial dan mengontrol agar tidak terjadi konflik horizontal antar masyarakat Indonesia. Setelah mengalami proses diskusi yang cukup panjang dan alot, baik dari kalangan pemerintah pusat, daerah, dan beberapa organisasi masyarakat (ormas), dimana pemerintah pusat (DPR) sudah membincangkan fakta ini mulai sejak tahun 1997 yang berupa RUU APP (Rancangan Undang-Undang Anti Pornografi dan Pornoaksi) dan draf RUU APP ini pertama kali diajukan pada tanggal 14 Februari 2006, akhirya RUU APP ini disahkan pada tahun 2008 menjadi UU Pornografi. ${ }^{1}$

Setelah UU No. 44 tahun 2008 ini disahkan, ternyata menimbulkan banyak protes dan ketidak setujuan berupa aksi balik dari beberapa masyarakat Indonesia, misalkan saja masyarakat Bali. Aksi dari masyarakat bali tersebut dipimpin langsung oleh Made Mangku Pastike sebagai gubernur Bali dan Ide Bagus Wasnawa selaku ketua DPRD Bali. Mereka tidak tanggung-tanggung mengancam akan menggugat dan menguji UU APP tersebut ke Mahkamah Konstitusi. Tidak sekedar masyarakat Bali yang melakukan penolakan terhadap UU itu, namun beberapa masyarakat Indoesia lainnya, seperti masyarakat Papua Barat, NTT, Sulawesi Utara, Sumatra Utara, Papua, dan beberapa LSM Perempuan lainnya juga menolak UU

${ }^{1}$ Wikipedia, "Undang-Undang Pornografi," last modified 2021, https://id.wikipedia.org/wiki/Undang-Undang_Pornografi. 
APP itu. Masyarakat Papua diwakili oleh Jimmya Demianus Ijie selaku ketua DPRD Papua Barat, dan masyarakat NTT diwakili oleh Drs. Frans Lebu Raya selaku gubernur NTT. Beberapa masyarakat Indonesia yang tidak setuju atau kontra dengan Undang-Undang disebutkan di atas, mereka tidak saja sebatas menyampaikan sikap kontra atau menolak terhadap UU APP, namun yang lebih menghebohkan lagi adalah isu untuk memisahkan diri dari Negara Kesatuan Republik Indonesia (NKRI). ${ }^{2}$

\section{B. Sosiologi Hukum dan Warna Terkini Kajian Ilmu Hukum}

Kemunculan sosiologi hukum ditengah-tengah kesibukan dunia akademik tidak bisa dilepaskan dari penegakan hukum yang terlalu positifistik dan jauh dari harapan masyarakat. Beberapa akademisi di bidang hukum kemudian menganggap bahwa penegakan hukum semacam ini terlalu memaksakan pendekatan kaca mata kuda dalam mengkaji hukum. Dalam konteks Indonesia, salah satu akademisi yang menggugat pemikiran dan pendekatan positifisme hukum adalah Jawahir Thontowi. Dalam tulisannya Paradigma Profetik Dalam Pengajaran dan Penelitian Ilmu Hukum, Jawahir sempat mengatakan bahwa model pendidikan ilmu hukum selama ini, yang dimulai sejak masa proklamasi kemerdekaan Indonesia hingga sekarang secara kualitas belum mampu menciptakan lulusan yang sanggup menjalankan tugasnya secara professional baik dari lingkungan perguruan tinggi Negeri maupun institusi Swasta. Fakta ini desebabkan oleh pemahaman terhadap hukum yang terkesan terlalu sempit, selama ini hukum dipandang dan dipergunakan hanya sebagai alat (tool) yang bebas nilai, sehingga berimplikasi terhadap pendidikan hukum yang selalu menggunakan satu lensa yaitu kaca mata kuda (positivism doctrine). Ketidak cermatan para sarjana hukum mengembangkan keilmuan hukum itu diperparah lagi dengan penelitian-penelitian hukum yang terlalu dogmatis, sehingga fakta-fakta empiris yang ada dilapangan selalu dilupakan

2 Ibid. 
oleh para peneliti-peneliti hukum yang memahami hukum sebatas pada sisi positifistik belaka. ${ }^{3}$

Kemunculan sosiologi hukum menjadikan dunia hukum lebih berwarna, meskipun beberapa kalangan menganggap bahwa sosiologi hukum merupakan anak pinak dari sosiologi bukan anak pinah dari hukum. Tentu anggapan ini tidak selamanya dapat dibenarkan dan tidak pula serta merta dapat disalahkan. Mengingat disiplin ilmu sosiologi hukum di Indonesia masih relatif cukup baru, sehingga sebuah kewajaran jika para mahasiswa yang pertama kali mempelajari sosiologi hukum merasa kesulitan untuk membedakan antara sosiologi, hukum, dan sosiologi hukum. Sebagai alternatif untuk merespon kegelisahan akademik para mahasiswa ini, Campbell dan Wiles menjelaskan bahwa sosiologi hukum secara khusus tentu berbeda dengan sosiologi secara umum dan berbeda juga dengan studi sosio-legal, namun sosiologi hukum merupakan disiplin ilmu yang mencarai dan menghubungkan antara ligel order dan sosial order, yang berfokus pada problemproblem justice dan pembaharuan hukum. ${ }^{4}$

Kajian sosiologi hukum ini sangat menyadari bahwa hukum tidak mungkin akan dipisahkan dari kehidupan nyata masyarakat. Hukum, manusia, dan masyarakat merupakan satu-kesatuan yang tidak bisa dipisahkan dalam kehidupan bermasyarakat, berkelompok, berhukum, dan dalam kehidupan lebih-lebih berbangsa dan bernegara. Berbicara hukum tentu harus berbicara tentang kehidupan manusia dan masyarakatnya secara kompleks. ${ }^{5}$ Dalam realitasnya, masyarakat selalu mengalami perkembangan dan perubahan yang sangat pesat dan dinamis, namun disisi lain terdapat hukum yang berfungsi sebagai sarana untuk melakukan kontrol sosial, ${ }^{6}$ yang berjalan dan berlari ditempat atau lamban. Stagnasi hukum semakin memperihatinkan ketika cara berhukum bangsa ini berbasis pada konsep mematikan hukum dalam bentuk tertulis, sehingga, mengakibatkan hukum

\footnotetext{
3 Jawahir Thontowi, “Paradigma Profetik Dalam Pengajaran Dan Penelitian Ilmu Hukum," Jurnal Unisia Jurnal Ilmu-Ilmu Sosial 36, no. 76 (2012): 86-87.

4 William M. Evan, The Sociology of Law: A. Social-Structural Perspektive (New York: The Free Press, 2010).

5 Sudikno Mertokusumo, Mengenal Hukum : Suatu Pengantar (Yogyakarta: Liberty, 2007).

${ }^{6}$ Donald Black, Social Control As A Dependent Variable, 2nd ed. (New York: Center for Criminal Justice Harvard Law School dan Academic Press, 1984).
} 
itu sama-sekali tidak mengalami perubahan sedikitpun dan tetap stagnan (statis) dalam formulasi lama. Stagnasi hukum inilah yang seringkali memicu ketidak becusan hukum dalam menyelesaikan persoalan masyarakat. Awalnya, masyarakat berharap hukum merupakan penyelesaian terakhir dalam mencari kebenaran dan keadilan. Tetapi, karena terperangkap dalam cara berhukum yang sangat kaku, maka hukum menjadi indikasi utama atas munculnya masalah baru dalam kehidupan berbangsa dan bernegara. Sebagai contohnya dalam hal ini adalah munculnya, UU No. 44 Tanun 2008. Keberadaan hukum itu tidak serta merta menjadikan kehidupan masyarakat menjadi lebih harmoni, melainkan memicu keretakan antar anak bangsa.

Akibat ketidak sanggupan hukum berlari kencang mengimbangi laju perubahan masyarakat yang sangat cepat, maka secara otomatis hukum tertinggal jauh atau terasingkan secara sendiri dari masyarakat. Sehingga, laju mayarakat yang sangat kencang, dan stagnasi hukum yang sangat kaku, menghendaki dan membutuhkan pembaharuan hukum, yang berfungsi untuk menjaga hukum supaya tetap aplikatif, stabil, atau "up to date" seirama dengan perkembangan masyarkat, maka dibutuhkan produk hukum baru yang berfungsi untuk menjaga stabilitas kehidupan sosial masyarakat. Jadi, perkembangan masyarakat yang sangat pesat ini harus diiringi dan direspon dengan perkembangan hukum yang pesat juga, sehingga akan terwujud keteraturan dalam masyarakat. ${ }^{7}$ Fakta inilah kemudian yang menjadi alasan penting atas terjadinya perubahan hukum itu sendiri.

C. Pro dan Kontra terhadap Undang-Undang Nomor 44 Tahun 2008 tentang Pornografi

Alasan kalangan yang kontra terhadap undang-undang ini adalah dikhawatirkan undang-undang tersebut akan membunuh kreatifitas para seniman; Kedua, Undang-Undang No. 44 Tahun 2008 ini dikhawatirkan mengancam pariwisata Indonesia; Ketiga, Undang-Undang No. 44 Tahun 2008 ini akan menghilangkan kebudayaan masyarakat Indonesia: Keempat, Undang-Undang No.

${ }^{7}$ Sudikno Mertokusumo, Penemuan Hukum: Sebuah Pengantar, Revisi. (Yogyakarta: Cahaya Atma Pustaka, 2014). 
44 Tahun 2008 ini dianggap tidak mendidik, karena akan menggeser kesadaran masyarakat untuk menjalankan moral yang mereka yakini; Kelima, mencegah industri pornografi bukan dengan cara membuat Undang-Undang No. 44 Tahun 2008 baru, namun dengan menguatkan Undang-Undang yang sudah ada; Keenam, tubuh manusia merupakan keindahan ciptaan Tuhan, sehingga patut untuk disyukuri; Ketujuh, anggapan bahwa masyarakat mayoritas akan menjadi tiran atas masyarakat minoritas; Kedelapan, Undang-Undang No. 44 Tahun 2008 ini dikhawatirkan akan menjadi pemicu disintegrasi bangsa. ${ }^{8}$

Dibalik beragam alasan-alasan para masyarakat yang kontra terhadap UndangUndang No. 44 Tahun 2008 Tentang Pornografi ini, terdapat juga berbagai sangkalan dari masyarakat yang pro terhadap UU ini dengan berbagai alas an, seprti yang diungkapkan oleh Kustiariyah 11 merupakan staf peneliti PKSPL dan juga sekaligus selaku dosen THP IPB mengatakan bahwa: ${ }^{9}$

"Diadopsinya aturan-aturan yang bersumber dari Islam dalam beberapa aturan yang diterapkan di Negara ini, merupakan hal yang wajar mengingat mayoritas warga Negara adalah Muslim. Justru aneh jika warga Negara yang notaben (mayoritas) muslim lebih memilih hukum warisan Belanda dari pada hukum yang berasal dari Islam. Penerapan beberapa aturan yang di dalamya diadopsi hukumhukum Islam, seringkali dianggap sebagai sebuah aturan yang tidak membumi. Sehingga wajar kemudian muncul pendapat "untuk apa dibuat suatu aturan jika kemudian banyak menimbulkan pelanggaran? Lebih baik tidak perlu ada aturan tersebut". Atau sebagain kalangan berpendapat, sebuah aturan hanya akan membatasi gerak-gerik seseorang. Bahkan sebuah aturan dianggap akan memperlakukan manusia sebagai robot."

Setelah membaca beberapa pasal dari UU No. 44 tahun 2008 tentang pornografi, ada beberapa kesimpulan yang dapat disimpulkan, diantaranya adalah dibelakang pro dan kontra Undang-Undang ini tentu terdapat hikmah positif, salah satunya bermunculannya berbagai tulisan dan gagasan konstruktif mengenai aturan hukum pornografi ini. Selain itu, realitas ini juga mengajarkan kedewasaan kepada segenap masyarakat, bangsa, dan negara Indonesia. Penulis melihat bahwa aturan hukum tentang pornografi ini memiliki misi untuk melindungi generasi bangsa (pemuda

\footnotetext{
${ }^{8}$ Habibullah, "Telaah Penolakan Undang-Undang Pronografi Dan Pornoaksi," Https://Fakagamauisu.Wordpress.Com.

${ }^{9}$ Rahmani Timorita Yulianti, "Pro Dan Kontra Undang-Undang Anti Pornografi Dan Pornoaksi," Al-Mawardi 15 (2006): 41.
} 
dan anak-anak) dari berbagai dampak arus globalisasi yang disimbolkan dengan kemudahan mengakses berbagai informasi, baik dari dalam maupun luar negeri (Pasal 15 UU No. 44/2008). Tidak sedekdar perorangan yang berkewajiban menjaga generasi bangsa dari dampak kerusakan moral, namun lembaga-lembaga tertentu juga memiliki tanggung jawab terhadap itu (Pasal 16 ayat 1 UU No. 44/2008). Berangkat dari beberapa alasan tersebut, penulis melihat bahwa undang-undang ini bertujuan untuk melindungi harkat dan martabat para generasi bangsa (anak-anak dan para pemuda) melalui moralitas budaya ketimuran yang bernuansa Keindonesiaan. Meskipun demikian, negara tetap harus memastikan bahwa keadilan dan kesejahteraan harus menjadi prioritas paling utama dalam kehidupan berbangsa dan bernegara. Jangan sampai kebenaran ala masyarakat minoritas dikorbankan atas dasar egoisme idiologis dari kalangan masyarakat mayoritas. Sebagai organisasi tertinggi di negeri ini, negara harus dapat memastikan bahwa semua kebenaran dan keadilan tidak pernah akan dikorbankan atas dasar egoisme masyarakat mayoritas. Negara datang untuk melindungi semua kebenaran dan keadilan yang ada, baik kebenaran dan keadilan bagi masyarakat mayoritas lebihlebih bagi masyarakat minoritas.

\section{Hukum dan Keselamatan Manusia}

Berangkat dari sepercik ulasan di atas mengenai kontroversi Undang-Undang No. 44 tahun 2008 tentang Pornografi, baik dari kubu yang pro terhadap UU itu maupun dari kubu yang kontra dengan UU tersebut merupakan masyarakat Indonesia. Sebelum penulis menganalisa lebih jauh mengenai permasalahan ini, terlebih dahulu saya akan menyampaikan beberapa teori yang akan pemakalah gunakan untuk menganalisa kasus di atas, tentu dengan menggunakan pendekatan yang jelas. Untuk melihat gejolak sosial di atas, maka pada makalah yang sangat singkat ini akan menggunakan lensa normative dan sosial budaya. Sehubungan dengan ini, salah satu ungkapan yang paling dekat dengan sosiologi hukum adalah 
penjelasan tentang miror tieri, yang menjelaskan bahwa hukum merupakan hasil refleksi dari masyarakat. ${ }^{10}$

Melanjutkan teori miror di atas, maka pada renah filsafat hukum Islam akan menggunakan teori Maqasid al-Syari'ah dan ayat-ayat Al-Quran mengenai pluralitas beragama sebagai landasan normatif, dan pada renah sosial budaya akan menggunakan teori fungsional struktural dari Talcott Persons. Mengenai teori maqāsid al-shariahh, akan merujuk pada Muhammad Said Ramadhan al-Buthi dalam karyanya berjudul Dawāit al-Mashlahāti fi al-Syariati Al-Islām, al-Buthi memberikan beberapa kriteria yang harus diperhatikan ketika menggunakan maqasid al-syariah, yakni ada

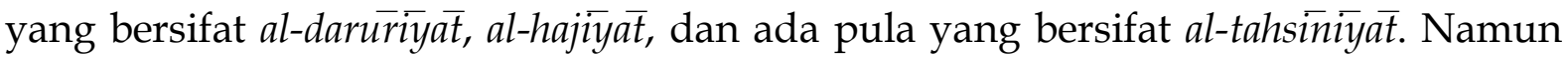
semua ini harus saling melengkapi untuk menuju cita-cita atau target yang maksimal, sehingga diharapkan akan terwujud suatu kehidupan yang baik. ${ }^{11}$

Yudian menyatakan bahwa maqāsid al-shariāh terbagi atas tiga skala prioritas yang saling melengkapi. Pertama, al-darüriyat "keharusan-keharusan" atau "keniscayaan-keniscayaan", yaitu sesuatu yang harus ada demi kelangsungan kehidupan manusia. Jika sesuatu itu tidak ada, maka kehidupan manusia pasti akan hancur. Tujuan-tujuan daruri itu adalah menyelamatkan agama, jiwa, akal, harta, keturunan dan harga diri (hurmah, pride atau kehormatan). Misalnya, untuk menyelamatkan jiwa, Quran memerintahkan agar manusia makan, tetapi tidak boleh berlebihan. Kedua, al-hajiyat atau "kebutuhan-kebutuhan". Atrinya, sesuatu dibutuhkan demi kelangsungan kehidupan manusia. Jika sesuatu itu tidak ada, maka kehidupan manusia tidak akan mengalami kehancuran, tetapi kesulitankesulitan akan menghadang. Misalnya, untuk makan dibutuhkan alat masak. Tanpa kompor, manusia masih dapat memasak nasi, tetapi kehadiran kompor akan memudahkan proses pencapaian tujuan masak nasi. Ketiga, al-tahsin̄iy $\bar{a}$ atau prosesproses dekoratif-ornamental. Artinya, ketiadaan hal-hal dekoratif-ornamental tidak akan menghancurkan tujuan daruri. Misalnya, orang bebas memilih warna apa saja

\footnotetext{
10 Brian. Z Tamanaha, A Companion to Philosophy of Law and Legal Theory, 2nd ed. (United Kingdom: Wiley Blackwel Publishing, 2010).

${ }^{11}$ Muhammad Said Ramadhan Al-Buthi, Dhawāith Al-Mashlahah Fí-Al-Syarīati Al-Islām (Makkah: Dar al-Fikr, 2010).
} 
untuk dekorasi kompor kesayangannya. Disinilah kaum minimum diberikan peluang seluas-luasnya. ${ }^{12}$

Pada dasarnya, konsep maqāid al-shariāh jauh hari sudah dibicarakan oleh beberapa cendikiawan Muslim, misalnya, 7 (tujuh) abad silam seorang intlektual Islam Granada benama Abu Ishaq Ibrahim Ibn Musa Al-Syarnathi, popular dengan sebutan Al-Syathibi (w.790H/1388M), dimana kata Al-Syathibi disandarkan kepada nama sebuah negeri tempat kediaman keluarganya, yakni Syathibah (Xativa atau Jativa). ${ }^{13}$ Sebelum Al-Syathibi, konsep maqāsid al-shariāh sudah diperkenalkan oleh Abd Al-Malik Al-Juwayni (w. 407 H/1185 M). Al-Juwaini dipercaya sebagai ulama Islam pertama yang memperkenalkan teori maqasid syariah ini dengan istilah Maqasid dan Masalih Al-Ammah. ${ }^{14}$ Setelah Al-Juwaini, Abu Hamid Al-Gozzali (w. 505 H/1111 M) dipercaya sebagai orang yang mengembangkan konsep maqāsid al-shariāh pada masanya, yang dibumikannya dengan istilah maslahah mursalah. Maslahah mursalah Al-Gazzali ini diasumsikan sebagai pengembangan dari teori yang dielaborasi terlebih dahulu oleh Al-Juwaini, asumsi ini didasari dari beberapa kajian para sarjana kontemporer terhadap kitab-kitab klasik Islam. Setelah Al-Gazzali, muncul beberapa nama belakangan yang dipercaya sebagai regenerasi konsep maqāsid al-shariāh, seperti Fakhruddin Al-Razi (w. 606 H/1209 M) dan Al-Amidi (w. 631 H/1234 M) yang tetap menggunakan istilah Al-Gazzali, dan tercatat sebagai pengikut Imam Al-Gazzali. setelah Al-Razi dan Al-Amidi, muncul kemudian Najmuddin Al-Tufi (w.716 H/ 1316 M) yang menegaskan bahwa maqāsid al-shariāh tidak lain dari sebab-sebab yang mengantarkan kepada Syariah. ${ }^{15}$

Pada hal daruriyat harus terdapat lima unsur penting yang tidak boleh dilupakan dan ditinggalkan yakni hifzu al-Dī, hifzu al-nafs, hifzu al-nasl, hifzu al-aqlu, dan hifzu al-matu. Sedangkan al-hajīyat merupakan tindak lanjut dari al-daruriya $\bar{t}$, dimana jika tidak ada al-hajiy $\overline{a t}$ maka akan mengakibatkan kepincangan pada aldaruriyāt di atas, atau al-hajiyāt bisa disebut sebagai sarana untuk mendapatkan

\footnotetext{
12 Yudian Wahyudi, Maqashid Syari'ah Dalam Pergumulan Politik “Berfilsafat Hukum Islam Dari Harvard Ke Sunan Kalijaga (Yogyakarta: Newsea, 2014).

${ }^{13}$ Hamka Haq, Al-Syathibi (Jakarta: Erlangga, 2007).

14 Jaser Audah, Al-Maqashid Untuk Pemula (Yogyakarta: Suka Press, 2013).

${ }^{15}$ Jaser Audah, Maqasyid Syariah as Philosophy of Islamic Law a Syistems Approach (London: The Internasional Institute of Islamic Thought, 2007).
} 
kemudahan dalam menghadapi kehidupan. Terakhir adalah tahsinīyat yakni salah satu unsur yang jika tidak terpenuhi maka tidak akan mengakibatkan ketidak sahan dari al-daruriyat di atas, namun akan mengakibatkan kekurang sempurnaan dari konsep al-daruriyat tersebut. Dengan kata lain bahwa, tahsiniy merupakan aktifitas yang menjadi tuntunan terhadap seseorang dalam bertindak, yang bertujuan untuk menciptakan suasana nyaman melalui tata krama, kesopanan, dan lain sebagainya. ${ }^{16}$

Sedangkan beberapa ayat-ayat Al-Qur'an mengenai pluralitas beragama yang dimaksud adalah ayat-ayat sebagai berikut: "tidak ada paksaan dalam beragama" (AlBaqarah [256]). ${ }^{17}$ "untukmu agamamu, dan untukku agamaku" (Al-Kafirun [6]). 18 dan ayat yang berbunyi "maka disebabkan rahmat dari Allah-lah kamu berlaku lemah lembut terhadap mereka. Sekiranya kamu bersikap keras lagi berhati kasar, tentulah meeka menjauhkan diri dari sekelilingmu. Karena itu maafkanlah mereka, mohonkanlah ampum bagi mereka, dan bermusyawarahlah dengan mereka dalam urusan itu. Kemudian apabila kamu telah membulatkan tekad, maka bertakwalah kepada Allah. Sesungguhnya Allah menyukai orang-orang yang bertawakkal kepadanya (Allah)" (Al-Imran [159]). ${ }^{19}$ Ayat ini jelas menegaskan bahwa materi hukum dan emosi positif penegak hukum harus sejalan bersamaan, sehingga tujuan dan fungsi hukum dapat terealisasi dengan baik.

Roger Cotterel mengatakan bahwa semua hukum memiliki tujuan dan fungsi yang spesifik, tujuan dan fungsi ini bertujuan tidak lain hanya sebagai alat untuk mengukur keefektifan suatu hukum. Sehingga, ungkapan mengenai masyarakat sebagai satu kesatuan yang kompleks dan terintegrasi secara menyeluruh, bukanlah sebatas analisis metodelogis sosiologis, namun bagian dari pandangan tertentu mengenai masyarakat. ${ }^{20}$ Teori Sistem Sosial Talcott Parsons yang terkenal dengan teori fungsional struktural, dimana teori ini mencoba mengembangkan paradigma empat fungsi yang menegaskan bahwa setiap sistem tindakan mengalami empat problem fungsional dalam mepertahankan eksistensinya, diantaranya adalah

\footnotetext{
${ }^{16}$ Yudian Wahyudi, Ushul Fikih versus Hermeneutika "Membaca Islam Dari Kanada Dan Amerika", 8th ed. (Yogyakarta: Newsea, 2014).

17 Departemen Agama RI, Al-Qur'an Dan Terjemahan (Jakarta: Pustaka Amani, 2006).

18 Ibid.

19 Ibid.

${ }^{20}$ Roger Cotterrel, Sosiologi Hukum, ed. Narulita Yusron (Bandung: Nusa media, 2012).
} 
Adaptation, Goal Attainment, Integration, dan Latent Pattern Maintenance. ${ }^{21}$ Secara umum atau pada dasarnya teori ini berangkat dari beberapa asumsi sebagai berikut: pertama, realita sosial dipandang sebagai suatu sistem; kedua, proses suatu sistem hanyalah dapat difahami dalam kerangka hubungan timbal-balik antara bagianbagiannya; ketiga, sebagaimana halnya dengan suatu organism, suatu sistem terikat pada proses-proses tertentu yang bertujuan untuk mempertimbangkan integritas dan batas-batasnya. Teori ini kemudian mencakup konsep-konsep sebagai berikut: pertama, sebagai sistem yang terikat dan terbatas, masyarakat mengatur dirinya sendiri dan cendrung menjadi suatu sistem yang tetap serta serasi; kedua, sebagai suatu sistem yang mengatur dirinya sendiri yang sama dengan suatu organism, masyarakat mungkin mempunyai berbagai kebutuhan dasar yang harus dipenuhi, apabila keserasiannya ingin dipertahankan; ketiga, analisa sosiologis terhadap sistem yang mengatur dirinya dengan segala kebutuhannya harus dipusatkan pada fungsi bagian-bagian sistem dalam memenuhi kebutuhan dan memelihara keserasian; keempat, dalam sistem-sistem dengan berbagai kebutuhan, mungkin tipe-tipe struktur tertentu harus ada untuk menjamin ketahannya. ${ }^{22}$ Namun dalam struktur normative, Parsons juga memberikan struktur atau hirarki fungsional yang terdapat dalam masyarakat, yakni: nilai-nilai, norma-norma, kolektifitas, dan peran. $^{23}$

Namun dalam struktur normative, Parsons juga memberikan struktur atau hirarki fungsional yang terdapat dalam masyarakat, yakni: nilai-nilai, norma-norma, kolektifitas, dan peran. Kemudian (G) adalah Goal Attainment yang bermaksud untuk menegaskan bahwa suatu sistem harus mampu untuk mencapai tujuan utamanya atau targetnya. Selanjutnya (I) adalah Integration, dimana poin ini menegaskan bahwa suatu sistem harus mampu menjaga hubungan baik atau intens dengan bagian-bagian yang menjadi komponennya. Dan huruf (L) bermakna adalah Latent Pattern Maintenace, memiliki maksud bahwa suatu sistem harus mampu sebagai aktor yang selalu memelihara pola-pola yang sudah ada dalam

\footnotetext{
21 Peter Beilharz, Teori-Teori Sosial, ed. Sigit Jatmiko (Yogyakarta: Pustaka Pelajar, 2005); Nanang Martono, Sosiologi Perubahan Sosial (Jakarta: Rajawali Pers, 2012).

22 Soerjono Soekanto, Talcot Persons “Fungsionalisme Imperatif" (Jakarta: Rajawali Pers, 1986).

${ }^{23}$ Cotterrel, Sosiologi Hukum.
} 
kelompoknya. ${ }^{24}$ Sedangkan maksud dari Struktur Normatif dari Talcott Persons di atas adalah sebagai berikut; pertama, nilai-nilai masyarakat adalah konsepsikonsepsi nilai yang ideal dalam bermasyarakat yang diinginkan oleh suatu masyarakat, dan nilai-nilai ini melekat erat dalam institusi-institusi sosial, sehingga nilai-nilai ini menjelma menjadi suatu struktur yang berperan sebagai pengatur sebuah sistem sosial masyarakat. ${ }^{25}$

Kedua, norma-norma kemasyarakatan, dimana norma ini pada kondisi khusus merupakan bentuk aplikasi dan refleksi dari nilai-nilai fundamental yang bersumber dari kelompok masyarakat yang secarang fungsional telah terdiferensiasi dalam subsistem masyarakat. Kemudian pada bagian ketiga adalah kolektifitas yang menjelaskan mengenai ketentuan terhadap pola-pola tindakan pada situasi yang spesifik. Dan keempat adalah peran-peran Individu, pada tahap ini menghendaki ekspektasi normative yang melekat pada tindakan-tindakan dari individu tertentu sebagai anggota dari kolektifitas. ${ }^{26}$

E. Membaca Undang-Undang No. 44 Tahun 2008 Tentang Pornografi dari Perspektif Maqasid Syariah dan Fungsional Struktural

Melihat kasus mengenai konflik antara kubu yang pro dan kontra terhadap undang-undang pornografi ini tentu sangat memprihatinkan, realita ini menunjukkan bahwa masyarakat Indonesia masih sebatas masyarakat plural namun belum siap untuk menjadi masyarakat multikultural. Hemat penulis latar belakang konflik ini terjadi sebenarnya disebabkan oleh kekerdilan jiwa dan mental para elit politik, agama, dan tokoh masyarakat, sikap semacam ini kemudian yang memicu konflik horizontal antar masyarakat terjadi. Alasan inilah yang mendorong penulis melihat sikap pro dan kontra masyarakat itu dengan teori maqasid al-shariāh dan teori sosialnya Talcott Persons tentang fungsional structural dalam masyarakat. Pada konteks aplikatif, disini Negara diposisikan sebagai organisasi tertinggi masyarakat Indonesia yang memiliki kekuatan penuh untuk mengontrol warga negaranya. Jika

\footnotetext{
24 Martono, Sosiologi Perubahan Sosial.

${ }^{25}$ Beilharz, Teori-Teori Sosial.

26 Ibid.
} 
berangkat dari teori fungsional strukturalnya Parsons yang mengatakan bahwa empat kendala suatu organisasi dalam mempertahankan dirinya, yakni adaptasi, pencapaian tujuan, integrasi, dan keadaan laten dalam arti suatu organisasi dituntut untuk mampu menjaga pola-pola yang sudah ada pada kelompoknya alias mampu bertahan dan beradaptasi dengan struktur sosial yang ada.

Apabila ditinjau dari perspektif maqasid syariah terhadap sikap pro dan kontra masyarakat Indonesia mengenai realitas di atas, dapat dikatakan bahwa masyarakat Muslim sebagai mayoritas satu sisi sangat wajar, tetapi sisi lain kurang mempertimbangkan narasi masyarakat minoritas lainnya. Masyarakat Muslim Indonesia sebagai mayoritas dari penggagas undang-undang ini adalah mengalami beberapa kelemahan, kelemahan yang penulis lihat disini adalah masyarakat muslim mempunyai niat dan ide yang baik namun tidak menempuh pendekatan merangkul dalam merealisasikan gagasannya itu. Seyogyanya masyarakat muslim selaku masyarakat mayoritas bersikap melindungi masyarakat minoritas, terutama mengenai agama dan kepercayaan masyarakat minoritas, karena pemeliharaan agama ini merupakan hal yang dijamin dalam dokrtin maqāsid al-shariāh dalam hukum Islam.

Kelemahan kedua dari masyarakat muslim adalah sikap yang terlalu berambisi dan cendrung egoistik terhadap pemberlakuan aturan hukum Pornografi ini, sehingga terkesan mengambil tindakan yang beraroma kekerasan. Akibatnya, salah satu unsur penting maqāsid al-shariāh berupa pemeliharaan jiwa dan raga masyarakat minoritas mengalami keterusikan, alias menyimpang dari doktrin maqasid al-shariāh. Sebagai masyarakat mayoritas, masyarakat muslim Indonesea seyogyanya berprilaku komunikatif terhadap masyarakat minoritas, sehingga jiwa dan raga masyarakat minoritas dapat terlindungi. Hal ini misalnya terlihat pada tindakan beberapa ormas Muslim yang mengangkat suara dengan keras layaknya orang yang terancam dan tertindas, dan seringkali seperti orang yang sedang memburu kemerdekaan. Pada konteks ini penulis melihat bahwa masyarakat muslim telah melanggar ketentuan mengenai ajaran berprilaku lemah lembut dalam mengajak orang untuk melakukan kebaikan. 
Kelemahan ketiga dari sikap umat muslim terutama para tokoh-tokoh masyarakat muslim adalah tidak membaca kondisi sosial ekonomi masyarakat minoritas secara komprehensif atau holistik. Hasilnya, muncul bacaan secara parsial yang menyimpulkan aturan hukum itu ansih tentang ruang gerak masyarakat muslim, dan terkesan masyarakat minoritas diabaikan seperti masyarat Bali. Penilis melihat ada beberapa alasan mengapa masyarakat Bali menolak UU No. 44 tahun 2008 ini, pertama, keberadaan UU ini dianggap akan mengancam obyek wisata di Bali, karena selama ini Bali bisa dikatakan memili obyek wisata yang memfasilitasi wisatawan lokal maupun manca negara dengan aturan hukum undang-undang Pornografi tersebut. Kedua, dengan berkurangnya wisatawan ke-Bali maka akan mengancam perekonomian masyarakat Bali, karena pendapatan Bali paling besar adalah melalui pariwisata. Ketiga, jika obyek wisata Bali mengalami penurunan, maka yang akan menjadi korban adalah masyarakat pribumi Bali, karena masyarakat Bali mayoritas adalah pekebun, dan hasil perkebunan pada dasarnya diminati oleh para wisatawan, ini bisa dilihat dari bentuk pulau bali yang didominasi oleh pegunungan. Berangkat dari alasan sosiologis tersebut, penulis menyimpulakan bahwa masyarakat muslim sebagai mayoritas sejatinya harus mampu melindungi perekonomian masyarakat minoritas, dan ketentuan inilah menurut hemat penulis dikategorikan sebagai pemeliharaan harta dalam konep maqāsid al-shariāh yang tidak lain tujuannya untuk menjamin kehidupan yang layak buat masyarakat minoritas.

Kelemahan keempat, masyarakat mayoritas tidak komunikatif dalam memberikan pemahaman-pemahaman mengenai tujuan dan manfaat dari UndangUndang Pornografi, sehingga terjadi ketidak sepahaman dan keselarasan dengan keinginan masyarakat minoritaslah yang memicu konflik terjadi. Kemudian pada renah inilah yang ingin dilindungi oleh konsep pemeliharaan akal dalam teori maqāsid al-shariāh, dengan arti lain adalah diperlukan pembelajaran dan musyawarah untuk menyelaraskan idea atau gagasan antara masyarakat minoritas dan mayoritas. Proses dapat diterima oleh akal sehat manusia menjadi bagian sangat penting dalam hal ini, sehingga, penyampaian berbasis ilmu pengetahuan menjadi sangat penting dalam melindungi akal dan budi pekerti. Dalam berbagai ajaran 
Islam, sangat banyak mengajarkan dan menjunjung tinggi tentang ajaran menyampaikan kebaikan melalui dengan cara berdiskusi ilmiah. Ajaran ini misalnya dapat ditemukan dalam Al-Quran, surat Al-Nahl, ayat 125.27 Ayat ini mengajarkan kepada seluruh umat manusia bahwa kebaikan hakekatnya harus juga disampaikan, dilakukan, dan dieksekusi dengan kebaikan. Indikasi penting dalam ajaran ini bahwa, jangan sampai kebaikan dieksekusi dengan cara yang tidak baik. Misalnya, makan merupakan kebutuhan paling mendasar bagi makhluk hidup untuk bertahan hidup, oleh karenanya, makanan yang dimakan oleh makhluk hidup harus yang baik-baik apbaila ingin tetap bertahan hidup. Makanan yang tidak baik misalnya makanan yang mengandung racun yang akan mengancam eksistensi kehidupan suatu makhluk hidup, oleh karenanya, agar makhluk hidup tersebut tetap selamat atau hidup, maka harus menghindari memakan makanan yang mengandung racun. Begitu juga dengan menyampaikan ajaran agama, menyampaikan ajaran agama merupakan kebaikan, sehingga dalam menyampaikannya juga harus dengan cara yang baik-baik atau bisa diterima berdasarkan martabat kemanusiaan seseorang. Jadi, menyampaikan acaran agama dengan cara baik-baik memiliki jalan yang sangat beragam, tidak selamanya yang ditempuh hanya satu jalan. Begitu juga dengan menyampaikan ajaran tentang moralitas agama, tidak selamanya yang ditempuh hanya satu cara yakni melalui teknil legal formal hukum negara. Tetapi, mengajarkan tentang moralitas agama bisa melalui sistem pendidikan yang bermartabat, sistem bisnis yang menjunjung kejujuran, sistem bermasyarakat, dan lain sebagainya.

Kemudian konsep terakhir dari maqā̄id al-shariāh adalah pemeliharaan keturunan, dalam konteks ini masyarakat mayoritas harus mampu menjaga dan melindungi generasi para masyarakat minoritas. Menjaga keturunan yang paling realistis dengan cara mempertimbangkan kesehatan dan perekonomian masyarakat minoritas. Masyarakat mayoritas berpotensi melanggar hukum karena memutus keberlanjutan perekonomian, pendidikan, dan kesehatan antar sesama warga negara dan anak bangsa. Melalui kesehatan, keturunan dan regenerasi akan terus berlanjut, dan melalui perkonomian, proses regenerasi akan terjamin kebutuhan hidup

${ }^{27}$ Departemen Agama RI, Al-Qur'an Dan Terjemahan. 
mereka. Melalui kebijaksanaan masyarakat muslim sebagai mayoritas tersebut, keamanan dan kenyamanan masyarakat minoritas berdampingan dengan masyarakat mayoritas dalam satu ikatan kewarganegaraan dapat terwujud. Perkara ini bisa dilihat salah satu contohnya dari Masyarakat Bali. Seperti yang disampaikan di atas, masyarakat Bali dalam menyelamatkan kebutuhan pokok atau primernya dari pariwisata, mereka makan, berjualan, bertahan hidup dari sektor itu. Keberadaan Undang-Undang No. 44 Tahun 2008 ini tentu secara otomatis akan mengancam keberlangsungan pariwisata di Bali, alhasil, jika keberlangsungan dunia pariwisata mati, maka akan mati juga kehidupan mereka. Mereka tidak dapat menjualkan hasil perkebunan, tidak dapat melanjutkan pendidikan, sulit menjamin kehidupan yang sehat karena keterbatasan perekonomian, dan lain sebagainya. Tentu pemeliharaan regenerasi masyarakat Bali harus menjadi perhatian serius masyarakat Islam sebagai penduduk mayoritas di Indonesia. Apabila masyarakat minoritas di Indonesia tidak sejahtera, maka wujud nyata dari kegagalan masyarakat mayoritas melindungi masyarakat minoritas. Tetapi, jika terdapat masyarakat minoritas lebih kaya dari masyarakat mayoritas, maka itu menunjukkan bahwa masyarakat mayoritas sangat berhasil mengayomi dan melindungi masyarakat minoritas. Sebagai contoh, beberapa tahun terakhir 10 orang terkaya di Indonesia, hanya ditemukan $10 \%$ beragama Islam, sedangkan 90\%nya Non Muslim. ${ }^{28}$ Realitas ini menunjukkan bahwa masyarakat Islam sebagai mayoritas di Indonesia sudah sangat berhasil mengayomi, melindungi, dan hidup berdampingan dengan masyarakat minoritas.

Jika kasus ini dilihat dari teori Parsons, maka ada beberapa kegagalan pemerintah pusat di dalam menjaga keharmonisan warga negaranya. Salah satu kegagalan pemertintah dalam meredam konflik horizontal masyarakat Indonesia mengenai pemberlakuan UU No. 44 tahun 2008 adalah pemerintah sebagai organisasi tertinggi masyarakat Indonesia tiadak mampu beradaptasi dengan harmoni terhadap semua kebudayaan masyarakatnya. Sehingga, pemerintah pada konteks ini hanya bisa beradaptasi dengan sistem nilai, budaya, tradisi, dan

28 Jususf Kalla, “Jusuf Kalla: 'Mayoritas Umat Islam Miskin'” (Indonesia, 2021), https:/ /lingkarkediri.pikiran-yakyat.com. 
pandangan keagamaan masyarakat minoritas, namun telah gagal beradaptasi dengan sistem nilai, budaya, tradisi, dan pandangan keagamaan, dan keberagaman pandangan hidup lainnya dari masyarakat minoritas. Konsekuensinya, masyarakat minoritas tidak dipedulikan atau dihiraukan oleh pemerintah. Jadi wajar jika beberapa masyarakat minoritas Indonesia seringkali mengancam untuk memisahkan diri dari Negara Kesatuan Republik Indonesia. Sikap pemerintah seperti ini beberapa tahun terakhir mulai menjadi trend terbarukan di beberapa daerah, misalnya munculnya Peraturan Daerah yang terkesan mementingkan sistem nilai, budaya, tradisi, dan pandangan keagamaan masyarakat mayoritas. Seperti Peraturan Daerah tentang Syariah, Peraturan Daerah tentang wisata Halal, dan sebagainya.

Kedua, Negara pada konteks ini tidak memegang prinsip pencapain tujuan secara komunalistik. Sebagai pemerintah, tidak saja yang diperhatikan hanya tercapainya tujuan masyarakat mayoritas, tetapi juga tujuan masyarakat minoritas diperhatikan secara berimbang. Sehingga, akan ada persamaan mengenai pencapaian tujuan antara masyarakat minoritas dan mayoritas. Penulis melihat, dalam konteks ini Negara hanya memperhatikan pencapaian tujuan masyarakat mayoritas semata. Sehingga suatu kewajaran jika masyarakat minoritas menyampaikan sikap terhadap pencapaian tujuan mereka tidak diakomudir oleh pemerintah. Seyogyanya Negara yang sudah paham betul dengan masyarakat Indonesia yang sangat pluralistik dan multietnis, multikulutral, dan seterusnya mempertimbangkan pencapaian tujuan bersama secara komunalistik, dimana masyarakat minoritas dan mayoritas dipenuhi target-target atau tujuan-tujuan mereka secara berimbang.

Kegagalan ketiga pemerintah pusat dalam mengawal UU No. 44 tahun 2008 ini adalah pemerintah tidak mengindahkan apa yang disebut Parsons sebagai integrasi. Dalam arti bahwa pemerintah sebagai organisai tertinggi masyarakat Indonesia harus mampu menjalin integrasi yang harmoni dengan semua lapisan masyarakatnya, tentu parameter harmoni di sini adalah melakukan sosialisasi dan dialog yang inten dengan beberapa masyarakat minoritas dan mayoritas. Kemudian, Negara harus mampu menjadi penengah (mediator) terhadap ketidak cocokan idea 
atau gagasan antara masyarakat minoritas dan mayoritas, disamping itu Negara harus mampu menekan atau mengontrol warga masyarakatnya untuk tidak melakukan penghakiman atau menarik kesimpulan sendiri. Sehingga melalui integrasi antara pemerintah dengan masyarakat, diharapkan akan menciptakan atmosper Indonesia yang tentram dan aman.

Kegagalan terakhir pemerintah dalam mengontrol ketegangan sosial mengenai pengesahan UU No. 44 tahun 2008 ini menurut analisa Parsons adalah pemerintah gagal menjaga apa yang disebut dengan keadaan latin atau pola-pola yang sudah ada pada jiwa masyarakat Indonesia. Hemat penulis, dalam konteks ini pola-pola yang dimaksud adalah sistem nilai masyarakat Indonesia mengenai batas bagian tubuh yang harus ditutupi sesuai dengan ajaran budaya lokal masyarakat Indonesia. Sehingga wajar jika beberapa masyarakat Indonesia menyampaikan sikapnya terhadap UU ini, karena dibeberapa daerah masyarakat Indonesia terdapat berbagai macam budaya berpakaian yang berbeda-beda. Masyarakat Indonesia yang tinggal di sabang memiliki pakaian adat yang sangat tertutup, dimana seperti yang telah diketahui bahwa semakin ketimur pakaian adat masyarakat Indonesia semakin terbuka. Sehingga suatu kewajaran jika persepsi masyarakat Indonesia berbeda-beda mengenai batas tubuh yang harus ditutupi. Kontroversi Undang-Undang ini tentu tidak bisa dipisahkan dari konteks budaya lokal atau adat istiadat masyarakat Indonesia, dan untuk menghindari konflik antara satu suku dengan suku yang lain pemerintah harus mampu melindungi semua pola-pola yang sudah ada pada masyarakatnya.

Kendala paling utama terhadap kegagalan suatu hukum adalah karena meninggalkan unsur sosialnya atau sosiologi hukumnya, sehingga ini berdampak pada ketidak cerdikan para pembuat hukum untuk membedakan hubungan fungsional antara kenyataan sosial dan jenis-jenis hukum. Alvin S. Johnson mengatakan perlu dibedakan dengan jelas antara jenis-jenis hukum (kinds of law), kerangka hukum (frameworks of law), dan sistem-sistem hukum (systems of law). ${ }^{29}$ Hukum jarang digali dari apa-apa yang dianggap baik oleh suatu masyarakat, sehingga mengakibatkan perlawanan-perlawanan yang cukup sengit dari

${ }^{29}$ Alvin. S. Johnson, Sosiologi Hukum, ed. Rinaldi Simamora (Jakarta: Rineka Cipta, 2006). 
masyarakat yang kurang mengenal aturan yang disahkan. Selaras dengan ini, maka Alvin S.Johnson mengatakan "tiap penjelmaan kenyataan sosial merupakan fakta normative yang dapat melahirkan hukum, yakni menjadi sumber utama atau sumber materiilnya, maka dapat disimpulkan bahwa fakta-fakta normative dari kelompok-kelompok dan masyarakat-masyarakat yang menyeluruh di dalam kehidupan hukum adalah lebih utama dari fakta-fakta normative dari kelompokkelompok yang khusus, dan yang terakhir ni merupakan lebih utama daripada fakta-fakta normative dari bentuk-bentuk kemasyarakatan". 30

\section{F. Kesimpulan}

Urian di atas tentang “Membaca Membaca Undang-Undang No. 44 Tahun 2008 Tentang Pornografi Dengan Perspektif Sosiologi Hukum" mencoba menyuguhkan kepada pembaca bahwa masyarakat yang pro dan masyarakat yang kontra terhadap aturan hukum Pornografi pada dasarnya tidak ada yang harus disalahkan. Masalah mulai muncul ketika tidak difasilitasi oleh komunikasi yang baik dan konstruktif. Permasalahan yang sangat signifikan terletak pada komunikasi yang kurang produktif antara para elit politik, agama, dan masyarakat. Dalam ajaran Islam, penutupan bagian tubuh (aurat) jika dikaji melalui maqāsid al-shariāh merupakan ajaran yang bersifat hajiyah dalam arti bahwa jika ketentuan ini dilanggar oleh umat Islam tidak akan menghilangkan identitasnya sebagai orang Islam. Menurut hukum Islam, menutup aurat sangat penting untuk menguatkan dan menyempurnakan ajaran daruriyat yang dimaksud di atas. Sedangkan Undang-Undang No. 44 tahun 2008 ini jika dikaji dari maqāid al-shariāh, persoalan yang diatur dalam UndangUndang ini masih bersifat tahsiniyat. Arti bahwa salah satu cara untuk memudahkan umat Islam dalam menjalani agamanya, sehingga, dengan tidak melakukan pengaturan secara legal formal saja umat Islam Indonesia masih tetap bisa menjalankan ajaran agama sebagaimana mestinya. Jadi, keberadaan tahsiniyyah ini hakekatnya hanyalah sebagai ornamental dalam mempercantik terwujudnya daruriyat dan hajiyat. Sinergitas antara tahsiniyat, hajiyat, dan daruriyat dalam mewujudkan cita-cita ideal hukum Islam akan mengantarkan kepada hakekat

30 Ibid. 
Keislaman yang Sejati. Islam akan terlihat senang dipandang mata, disenangi orang lain, orang merasa nyaman, dan seterusnya. Sehingga, apabila persoalan tahsinīyat tidak berhasil mempercantik ornamental keislaman yang ada dalam darurīya $\bar{t}$ dan hajiy $\overline{a t}$, maka ornamental itu lebih baik dihilangkan. Artinya, jika tindakan legalformal terhadap UU No. 44 tahun 2008 tersebut akan merusak keindahan Islam, maka lebih baik ornamen tersebut ditiadakan.

Realita ini diharapkan mampu menjadi pendewasaan terhadap semua masyarakat Indonesia, dimana niat yang baik jika tidak diikuti dengan metode yang baik akan menghasilkan malapetaka. Hemat penulis, siapa pun jika diajak untuk melakukan hal yang bararoma normative dan bermoral, saya kira pasti ada keinginan dan ketertarikan untuk hal itu, namun lagi-lagi permasalahannya adalah cara untuk mewujudkan tujuan mulia itu yang belum pas, masih terkesan cara pendek dan kekanak-kanakan, dan belum ditemukan sifat kedewasaan yang asli dari bangsa dan masyarakat yang berjiwa besar ini. Dalam analisa pendek saya, konflik ini pada dasarnya bukanlah kontroversi masyarakat pribumi Indonesia, namun saya melihat bahwa konflik ini merupakan persaingan budaya asing bukan budaya masyarakat Indonesia sendiri. Yakni, persaingan antara sistem nilai masyarakat timur dengan masyarakat barat, dimana masyarakat barat membawa isu

globalisasi dan lain-lain untuk mempertahankan dominasinya, sedangkan masyarakat timur sebagai masyarakat yang ingin mempertahankan eksistensi nilainilai masyarakat ketimuran sebagai unsur moralitas.

\section{Daftar Pustaka}

Al-Buthi, Muhammad Said Ramadhan. Dhawā̄ith Al-Mashlahah FíAl-Syarīati AlIslām. Makkah: Dar al-Fikr, 2010.

Audah, Jaser. Al-Maqashid Untuk Pemula. Yogyakarta: Suka Press, 2013.

- - - Maqasyid Syariah as Philosophy of Islamic Law a Syistems Approach. London: The Internasional Institute of Islamic Thought, 2007.

Beilharz, Peter. Teori-Teori Sosial. Edited by Sigit Jatmiko. Yogyakarta: Pustaka Pelajar, 2005.

Black, Donald. Social Control As A Dependent Variable. 2nd ed. New York: Center for 
Criminal Justice Harvard Law School dan Academic Press, 1984.

Cotterrel, Roger. Sosiologi Hukum. Edited by Narulita Yusron. Bandung: Nusa media, 2012.

Departemen Agama RI. Al-Qur'an Dan Terjemahan. Jakarta: Pustaka Amani, 2006. Habibullah. “Telaah Penolakan Undang-Undang Pronografi Dan Pornoaksi.”

Https://Fakagamauisu.Wordpress.Com.

Haq, Hamka. Al-Syathibi. Jakarta: Erlangga, 2007.

Johnson, Alvin. S. Sosiologi Hukum. Edited by Rinaldi Simamora. Jakarta: Rineka Cipta, 2006.

Kalla, Jususf. “Jusuf Kalla: 'Mayoritas Umat Islam Miskin.'” Indonesia, 2021. https:/ /lingkarkediri.pikiran-yakyat.com.

M. Evan, William. The Sociology of Law: A. Social-Structural Perspektive. New York: The Free Press, 2010.

Martono, Nanang. Sosiologi Perubahan Sosial. Jakarta: Rajawali Pers, 2012.

Mertokusumo, Sudikno. Mengenal Hukum : Suatu Pengantar. Yogyakarta: Liberty, 2007.

- - - Penemuan Hukum: Sebuah Pengantar. Revisi. Yogyakarta: Cahaya Atma Pustaka, 2014.

Soekanto, Soerjono. Talcot Persons "Fungsionalisme Imperatif." Jakarta: Rajawali Pers, 1986.

Tamanaha, Brian. Z. A Companion to Philosophy of Law and Legal Theory. 2nd ed. United Kingdom: Wiley Blackwel Publishing, 2010.

Thontowi, Jawahir. "Paradigma Profetik Dalam Pengajaran Dan Penelitian Ilmu Hukum." Jurnal Unisia Jurnal Ilmu-Ilmu Sosial 36, no. 76 (2012): 86-87.

Wahyudi, Yudian. Maqashid Syari'ah Dalam Pergumulan Politik "Berfilsafat Hukum Islam Dari Harvard Ke Sunan Kalijaga. Yogyakarta: Newsea, 2014.

- - - . Ushul Fikih versus Hermeneutika "Membaca Islam Dari Kanada Dan Amerika".

8th ed. Yogyakarta: Newsea, 2014.

Wikipedia. “Undang-Undang Pornografi.” Last modified 2021.

https://id.wikipedia.org/wiki/Undang-Undang_Pornografi.

Yulianti, Rahmani Timorita. "Pro Dan Kontra Undang-Undang Anti Pornografi Dan 
Pornoaksi." Al-Mawardi 15 (2006): 41. 